\title{
Comparative Proteomic Analysis of Esophageal Squamous Cell Carcinoma
}

\author{
Yijun $\mathrm{Qi}^{1,2}$, Jen-Fu Chiu ${ }^{3,4}$ Lidong Wang ${ }^{1}$, Dora L.W. Kwong ${ }^{5}$, and Qing-Yu He ${ }^{2,3^{*}}$ \\ ${ }^{1}$ Laboratory for Cancer Research, College of Medicine, Zhengzhou University, Zhengzhou; \\ ${ }^{2}$ Department of Chemistry, ${ }^{3}$ Open Laboratory of Chemical Biology of the Institute of \\ Molecular Technology for Drug Discovery and Synthesis, ${ }^{4}$ Institute of Molecular Biology, \\ and ${ }^{5}$ Department of Clinical Oncology, University of Hong Kong, Hong Kong, China
}

*Corresponding author: Dr. Qing-Yu He, Department of Chemistry, University of Hong Kong, Pokfulam, Hong Kong, China. Tel: (852)2299-0787, Fax: (852)2817-1006, E-mail: qyhe@hku.hk

Running title: Proteomics of esophageal squamous cell carcinoma

\section{Abbreviations used:}

ESCC, esophageal squamous cell carcinoma; SCCA1, squamous cell carcinoma antigen1; BCH, basal cell hyperplasia; DYS, displasia; CIS, carcinoma in situ; GAPDH, glyceraldehyde-3 phosphate dehydrogenase; NADP, isocitrate dehydrogenase; TPM, tropomyosin; PRX, peroxiredoxin; MnSOD, manganese-containing superoxied dismutase; $\alpha \mathbf{B}-$ Cryst, alpha B crystalline; ACN, acetonitrile.

Keywords: Proteomics, esophageal cancer, 2D-PAGE, protein profiling, tumor-associated proteins, SCCA1, peroxiredoxin, transgelin 


\section{ABSTRACT}

Ranking as the fourth commonest cancer, esophageal squamous cell carcinoma (ESCC) represents one of the leading causes of cancer death in China. One of the main reasons for the low survival rate is that neoplasms in esophagus are not detected until they have invaded into surrounding tissues or spread throughout the body at advanced stages. A better understanding of the malignant mechanism and early diagnosis are important for fighting ESCC. In this study, we used proteomics to analyze ESCC tissues, aiming at defining the proteomic features implicated in the multistage progression of esophageal carcinogenesis. Proteins that exhibited significantly different expressions were identified by peptide mass fingerprinting and validated by Western blotting and RT-PCR. The protein changes were then correlated to the different grades of disease differentiation. Compared to those in adjacent normal epitheliums, the expression of 15 proteins including enolase, elongation factor $\mathrm{Tu}$, isocitrate dehydrogenase (NADP), tubulin alpha-1 chain, tubulin beta-5 chain, actin (cytoplasmic 1), glyceraldehyde-3 phosphate dehydrogenase (GAPDH), tropomyosin isoform 4 (TPM4), prohibitin, peroxiredoxin 1 (PRX1), manganese-containing superoxied dismutase (MnSOD), neuronal protein and transgelin were up-regulated and the expression of 5 proteins including tropomyosin 1 (TPM1), squamous cell carcinoma antigen 1 (SCCA1), stratifin, peroxiredoxin 2 isoform a (PRX2) and alpha B crystalline ( $\alpha$ B-Cryst) were down-regulated in cancer tissues with a statistical significance $(\mathrm{p}<0.05)$. In addition, the differential expression of SCCA1, PRX1, MnSOD, TPM4 and prohibitin can be observed in precancerous lesions of ESCC. The expression of stratifin, prohibitin and SCCA1 dropped with increasing dedifferentiation of ESCC. These data may suggest that these proteins contribute to the multistage process of carcinogenesis, tumor progression and invasiveness of ESCC. 


\section{Introduction}

Esophageal squamous cell carcinoma (ESCC), the predominant histological subtype of esophageal cancer, is the fourth most common malignancy and still represents a great health concern in China. The incidence of ESCC is characterized by the striking geographic variation in incidence throughout the world $[1,2]$. Linzhou (formerly Linxian) and Huixian, which geologically belong to Taihang Mountain region in northern China, have the highest incidence of ESCC in the world, with an incidence rate of approximately 150 per 100,000 population [1]. Most of the patients cannot survive more than one year after presenting at healthcare centers and the 5-year survival rate for ESCC remains as low as 10 percent or even less due to complications caused by the aberrant tumor growth in the esophagus, such as dysphagia, cachexia, etc $[3,4]$. One of the main reasons for the ominous phenomena is that neoplasms in esophagus are not detected until they have invaded the surrounding tissues or spread throughout the body at advanced stages. The early detection and diagnosis of esophageal malignancy is critical for its therapy and management.

A large number of epidemiological studies suggested that cigarette smoking, alcohol drinking, diets deficiency in vitamins and/or protective antioxidants, thermal injuries caused by hot food, intake of nitrosamine or moldy foodstuff which contain direct or indirect carcinogen have been closely correlated to the prevalence of the esophageal cancer [5-7]. The etiological factors for ESCC, however, have yet to be clarified. Similar to other types of cancer, ESCC involves a multistage process, featuring a great diversity of genetic and epigenetic alternations. Although various molecular events and morphologic features have been found to closely correlate with malignancies of esophagus, the biomarkers for early detection and diagnosis with high specificity and sensitivity and indices for treatment and management of esophageal malignancy have not been identified. 
Proteomics provides an effective approach to study disease pathogenesis by globally examining the different protein expressions due to malignant cell transformation in disease [8, 9]. Proteomic technology has been successfully applied to identify tumor-associated proteins in various cancers originating from different organs including liver [10], lung [11], prostate [12], breast [13], kidney [14], tongue [15], buccal mucosa [16] esophagus [17], bladder [18], and cholangiole [19]. In this study, we employed proteomics to analyze ESCC tumor specimens recruited from Linzhou, China, to identify the proteins with significantly different expressions in cancer. The expression patterns of the proteins were then correlated to the different stages of malignancy and differentiation status of the disease. The present findings may shed light on the molecular characterization of esophageal cancer progression and may be informative for identifying biomarkers and therapeutic targets for ESCC. 


\section{Materials and Methods}

\subsection{Tissue specimen}

Tissues used in this experiment were obtained with the approval of the Committees for Ethical Review of Research involving Human Subjects at Zhengzhou University and the University of Hong Kong. A total of 17 human ESCC specimens were collected immediately after isolation of surgically resected tissues from patients in Linzhou in northern China. The 17 cases include 10 males and 7 females with averaged age of $60.2 \pm 7.3$ years. Tissue samples were snap-frozen in liquid nitrogen and then preserved in $-80^{\circ} \mathrm{C}$ deep freezer or on dry ice for transfer before experiments. The histology for all 17 samples was confirmed by two independent histopathologist following fixation, embedding, sectioning and $\mathrm{H} \& \mathrm{E}$ staining. All samples comprised more than $80 \%$ of target cells (normal epithelial cells, cells with various grades of disease or cancer cells) without necrosis. These 17 cases were divided into two groups (Table 1). Group 1 contains 15 pairs of intra-matched tissue specimens, i.e., tumor center tissues and matched normal esophageal epitheliums at least $5 \mathrm{~cm}$ distal from primary tumor mass of ESCC. Group 2 has two cases; each contains matched triplet samples including tumor and two pre-tumor lesions at different stages based on Lugol's staining (see below).

\subsection{Preparation of tissue protein samples}

Fresh frozen esophageal tissue samples (100-150 mg) were cut into small pieces, dissolved in lysis buffer at the ratio of $1 \mathrm{mg}$ tissue per $2 \mu \mathrm{l}$ lysis buffer (Reagent 3, Bio-Rad Laboratories, Hercules, CA, USA) containing protease inhibitor cocktail (Sigma, St. Louis, MO, USA) 8340 and DNase I 1 unit / $\mathrm{ml}$ and then homogenized for $5 \mathrm{~min}$ on ice with a minihomogenizer. The mixture was centrifuged at $13.2 \times 1000 \mathrm{rpm}$ at $4^{\circ} \mathrm{C}$ for $15 \mathrm{~min}$ to remove 
tissue and cell debris. The supernatant was taken as extracted proteins and the protein concentration was determined by the Bradford method with BSA as standard. Aliquots of protein samples were kept in $-80^{\circ} \mathrm{C}$ deep-freezer until further use.

\subsection{DE electrophoresis, silver staining and image analysis}

Isoelectronic focusing was conducted using Amersham Biosystems IPG-phor. IPG strips with a linear $\mathrm{pH}$ range of 3 to 10 were used for protein separation by following a protocol described previously $[15,20]$. Proteins of 30 to $50 \mu \mathrm{g}$ for analytical gels and 100 to $200 \mu \mathrm{g}$ for preparative gels were utilized for IEF and subsequent second dimensional separation. All samples were run at least in duplicate to guarantee reproducibility. Two good quality gels for each case were included into the subsequent image analysis. Silver staining was performed as previously described [15]. Images of 2D-gels were digitalized with ImageScanner (Amersham Biosciences). Image analyses were conducted with ImageMaster 2D Elite software 4.01 (Amersham Biosciences) [15]. The normalized value for each protein spot volume was used for comparison. Only those spots that have statistical significance in differential expression were selected for further investigation.

\subsection{In-gel digestion by trypsin}

Spots of interest were cut off with a clean scalpel after the preparative gels were washed with Mili-Q water and transferred to a siliconized Eppendorf tube. Stained gel slabs were cut into $1 \mathrm{x} 1 \mathrm{~mm}$ pieces and de-stained with $1 \mathrm{ml}$ of $1: 1(\mathrm{v} / \mathrm{v})$ mixture of $30 \mathrm{mM}$ potassium ferricyanide and $100 \mathrm{mM}$ sodium thiosulfate for $10 \mathrm{~min}$ and rinsed at least twice with Mili-Q water ( $1 \mathrm{ml}$ for $5 \mathrm{~min}$ each) until the yellow color disappeared. The gel slabs were equilibrated with $0.5 \mathrm{ml}$ of $50 \mathrm{mM} \mathrm{NH}_{4} \mathrm{HCO}_{3}$ for $10 \mathrm{~min}$ and then incubated with $0.5 \mathrm{ml}$ of $1: 1$ mixture of 
$50 \mathrm{mM} \mathrm{NH} \mathrm{HCO}_{3}$ and $100 \%$ acetonitrile $(\mathrm{ACN})$ for $30 \mathrm{~min}$. Complete dehydration was achieved by incubation of gel slabs with $200 \mu \mathrm{l}$ of $100 \%$ ACN and then gel pieces were dried in a Speed-Vac for $20 \mathrm{~min}$. For the in-gel digestion, the gel particles were rehydrated with a minimal volume of trypsin solution $\left(10 \mu \mathrm{g} / \mathrm{mL}\right.$ in $\left.25 \mathrm{mM} \mathrm{NH}_{4} \mathrm{HCO}_{3}\right)$ and incubated at $37^{\circ} \mathrm{C}$ overnight. The liquid fraction containing digested peptides was spotted onto a sample plate with equal amounts of matrix. Where necessary, the in-gel digests were extracted subsequently with $50 \%$ and $80 \%$ acetonitrile, and then concentrated and de-salted by Zip tips prior to applying on the sample plate [20].

\subsection{MALDI-TOF MS and protein identification by peptide fingerprinting}

A Voyage-DE STR MALDI-TOF mass spectrometer (Applied Biosystems, Foster City, CA, USA) was employed to obtain the peptide mass spectra with the following settings: reflector mode with $175 \mathrm{~ns}$ delay extraction time, $60-65 \%$ grid voltage and $20 \mathrm{kV}$ accelerating voltage. Laser shots of 250 per spectrum were used to acquire the spectra with mass range of 500-4000 Da. Mass calibration was performed by using autolytic fragment peaks of trypsin including 906.5049, 1153.5741 and 2163.0570 Da. Proteins were identified by peptide fingerprinting using MS-Fit to search the NCBInr protein database (http://prospector.ucsf.edu). The criteria for database matching are: $\pm 25 \mathrm{ppm}$ mass tolerance,

at least four peptides matched, and corresponding molecular weights and $\mathrm{p} I$ values. The species of origin was restricted to Homo Sapiens.

\subsection{Western blotting}

With reference to the verification of candidate proteins after peptide fingerprinting, the proteins of interest were selected for Western blotting to confirm the results of protein database searching. After 1D or 2D electrophoresis, proteins were transferred onto PVDF 
membranes (Amersham Biosciences) at $0.8 \mathrm{~mA}$ per $\mathrm{cm}^{2}$ for $1 \mathrm{~h}$. After blocking in $5 \%$ non-fat milk in TBS-T containing $0.1 \%$ Tween 20 (Sigma) at $4^{\circ} \mathrm{C}$ overnight with gentle rocking, membranes were probed with antibodies. Primary antibodies involved in this study include SCCA1 (SCCA1 8H11: sc-21767, Santa Cruz Biotechnology, Int.) diluted in 1:250, crystallin (SPA-223, Stressgen Biotechnologies) diluted in 1:2000, tropomyosin (TM311, Sigma) diluted in 1:400. Membranes were incubated with corresponding primary antibody for various durations according to the specificity and sensitivity of antibody. After incubation with corresponding secondary antibodies, immunoblots were visualized with the ECL detection kit (Amersham biosciences, Sweden, Uppsala). For re-probing membranes with another antibody, the membranes were stripped with stripping buffer (glycine $3.75 \mathrm{~g} / \mathrm{L}$, SDS $2 \mathrm{~g} / \mathrm{L}, \mathrm{pH} 2.0$ ) before blocking.

\subsection{RNA isolation and RT-PCR}

TRIZOL Reagent (GIBCOBRL, Life technologies, U.S.A) was used to isolate total RNA from frozen tissue samples according to protocol provided by supplier. Reverse transcription was performed using $3 \mu \mathrm{g}$ of extracted total RNA mixed with reaction mixture in a final concentration of $0.5 \mathrm{mM}$ dNTPs, $0.025 \mu \mathrm{g} / \mu \mathrm{l}$ oligo dT, $5 \mathrm{mM} \mathrm{MgCl}, 0.01 \mathrm{M}$ DTT, $2 \mathrm{U} / \mu \mathrm{l}$ RNaseOUTTM inhibitor and $2.5 \mathrm{U} / \mu \mathrm{l}$ SSII RT. The reaction was achieved by incubating each sample at $65^{\circ} \mathrm{C}$ for $5 \mathrm{~min}$, placing on ice for $1 \mathrm{~min}$, incubating at $42^{\circ} \mathrm{C}$ for 2 min, mixing with SSII RT followed by incubating at $42^{\circ} \mathrm{C}$ for 1 hour, and incubating at $70^{\circ} \mathrm{C}$ for 15 min to stop reaction. Following RT, PCR was carried out in a reaction volume of $30 \mu \mathrm{l}$ with final concentration of $1.5 \mathrm{mM} \mathrm{MgCl} 2,0.1 \mathrm{mM}$ dNTPs, 0.05 Taq DNA Polymerase and primer pair for SCCA1. Beta-actin was used for internal normalization. The primer used for SCCA1 and beta-actin are listed as follows. The reaction was initiated at $94^{\circ} \mathrm{C}$ for $10 \mathrm{~min}$ 
followed by 35 cycles at $94^{\circ} \mathrm{C}$ for $30 \mathrm{~s}, 55^{\circ} \mathrm{C}$ for $1 \mathrm{~min}$ and $72^{\circ} \mathrm{C}$ for $1 \mathrm{~min}$, and final extension at $72^{\circ} \mathrm{C}$ for $10 \mathrm{~min}$.

SCCA1, sense primer 5' GATTAAGAAGGTTCTTCACTTTGA 3', antisense primer 5'ATGTGGTATTGCTGCCAATATTACCTTCAGGAAT -3’;

Beta-actin, sense primer, 5'-GTGGGGCGCCCCAGGCACCA-3', antisense primer 5'CTCCTTAATGTCACGCACGATTTC 3’.

\subsection{Statistical analysis}

Since there are only two cases in group 2, the statistical analysis was performed only for the 15 paired samples in group 1. Comparison was made between 15 normal samples and 15 SCC tumor samples regardless their differentiation states. One-tailed Student's t-test was used for statistically analyzing the data extracted from comparison window of ImageMaster software that displayed the normalized volumes for each protein spot. A value of $p<0.05$ was considered significant. 


\section{Results}

\subsection{Histological diagnosis of ESCC specimens}

As shown in Figure $1 \&$ Table 1, two groups of tissue specimens were classified through detailed histological diagnosis. For the group 1, the 15 matched SCC tumor tissues can be further characterized according to their differentiations into three subgroups, including 1 well-differentiated, 5 moderately-differentiated and 9 poorly-differentiated SCC. The presence of ESCC and intra-matched epithelium were confirmed by subsequent histological examination in which tissue section slides were stained with hematoxylin and eosin (Fig. 1). For the group 2, Lugol's staining was performed before dissecting tissue specimens harboring precursor lesions of ESCC. Lugol's staining is a well-known procedure to screen out diseased conditions or precursor lesions of tumors originating from squamous epithelium, such as cervix of uterus and esophageal epithelium. Besides the cancer mass, adjacent non-stained and stained areas of esophageal epithelium in Lugol's staining were dissected. The nonstaining area of esophageal mucosae was considered to be precursor lesions for ESCC. As listed in the group 2 in Table 1, Case 23 comprised tissues of dysplasia (DYS), carcinoma in situ (CIS) and moderately-differentiated SCC; and Case 29 consisted of tissues of basal cell hyperproliferation (BCH), DYS and moderately-differentiated SCC, respectively (Fig. 1).

\subsection{DE protein separation and image analysis}

Two-dimensional electrophoresis using immobilized $\mathrm{pH}$ gradient (linear) ranging from 3 to 10 was performed to separate the proteins extracted from tumor and adjacent normal mucosa or precancerous tissue samples. Figure 2 shows one representative pair of proteome profilings for cancer (A) vs. normal (B) tissue samples. There were around 942 spots unambiguously displayed on the 2D-gels according to the image analysis using software ImageMaster 2D Elite. We found that most of the spots correlated well between 2D maps of 
cancer and adjacent non-tumor tissues. One-tailed Student's test was utilized to select the protein spots that showed significantly and consistently differences in expression through the intra-paired comparative analysis in ImageMaster. 24 protein spots were revealed to have differential expressions between cancer tissues and adjacent normal esophageal epitheliums with $\mathrm{p}$ values less than 0.05 (Table 2). Among these protein spots, 19 were up-regulated and 5 were significantly down-regulated in ESCC tumor. The numbers denoted on the 2DE maps in Figure 2 represent these protein spots; the supposed positions of the spots absent or undetectable on one image but present on its counterpart gel are also indicated. The most substantial volume change is for spot 808 , corresponding to a transgelin isoform, showing an averaged expression of 107-folds more in cancer tissues than in non-tumor tissues. In fact, for all the 17 paired cases, spot 808 was unequivocally displayed in 13 tumor cases but almost undetectable in the 2DE maps of normal tissues or tissues with precursor lesions of ESCC (Figure 3).

\subsection{Protein identification by peptide mass fingerprinting}

Protein spots with statistically consistent and significant differences in protein expression were exercised, subjected to in-gel tryptic digestion, MALDI-TOF mass spectral measurements and peptide mass fingerprinting to obtain protein IDs. Table 3 lists the identified protein IDs, together with corresponding spot numbers, molecular weights and $\mathrm{p} I$ values, peptides matched, sequence coverages, total mass errors, and MOWSE scores. For most of protein database matching, reasonable sequence coverage, low mass errors and high MOWSE scores were obtained. Proteins showing over-expressions in tumor are enolase, elongation factor $\mathrm{Tu}$, isocitrate dehydrogenase (NADP), tubulin alpha-1 chain, tubulin beta-5 chain, actin (cytoplasmic 1), glyceraldehyde-3 phosphate dehydrogenase (GAPDH), tropomyosin isoform 4 (TPM4), prohibitin, peroxiredoxin 1 (PRX1), manganese-containing 
superoxied dismutase (MnSOD), neuronal protein and transgelin. Proteins that were downregulated in tumor include tropomyosin 1 (TPM1), squamous cell carcinoma antigen 1 (SCCA1), stratifin, peroxiredoxin 2 isoform a (PRX2) and alpha $\mathrm{B}$ crystalline ( $\alpha \mathrm{B}-\mathrm{Cryst})$. Apparently different protein isoforms existed on proteomic profiling due to alternative splicing or post-translation modification. Proteins displaying isoforms are transgelin, GAPDH and alpha enolase.

\subsection{Correlation of protein expression with histological grades of ESCC}

The expression levels of the altered proteins were further correlated to the differentiation status of ESCC in Group 1. As depicted in Figure 4, we found that the expression changes for protein spots 376 (SCCA1), 586 (Stratifin) and 592 (Prohibitin) inversely correlate with differentiation grades of ESCC. The protein expression levels decreased with increasing dedifferentiation of ESCC from well-, to moderately- to poorlydifferentiated carcinoma.

Detailed protein expression analysis was also carried out for Group 2 that contains two matched triplets of specimens from the same patients. Figure 5 shows consistent correlation or tendency relationships between lesion grades and protein expressions in the two cases. Clearly, expression levels of protein spots 534 (TPM4), 592 (Prohibitin), 701 (PRX1) and 706 (MnSOD) linearly increased with progression of disease in the precancerous lesions from DYS to CIS (case 23) and from BCH to DYS (case 29) advancing to SCC. In addition, protein spot 376 (SCCA1) changed its expression level in reverse with the disease severity, consistent with the tendency found in Group 1. A negative linear relationship in terms of SCCA1 expression levels versus the general trend of disease aggravation can be derived. These protein alterations in expression reflect the dynamic molecular characterization of esophageal carcinogenesis. 


\subsection{Protein ID and expression confirmation by Western blotting}

Western blotting was performed to verify three selected proteins, SCCA1, TPM1 and $\alpha \mathrm{B}$-Cryst, that may play functional roles in tumorigenesis. Figure 6 shows the $2 \mathrm{D}$ Western blotting results with the corresponding silver staining $2 \mathrm{D}$-gels side by side for the three proteins. Specific and positive immunochemical interactions occurred for the three proteins evaluated. Figure 7A displays the representative gels of 1D Western blotting, confirming the decreased expressions of these three proteins in tumor tissues. Western blotting results shown in Figure 7B exhibit the expression levels of SCCA1, the disease antigen, in the precancerous lesions in the specimens of Group 2. In light with the data generated from the 2D-gel image analysis, SCCA1 expression levels in tissues decreased from DYS $\rightarrow$ CIS $\rightarrow$ SCC (case 23) and from $\mathrm{BCH} \rightarrow \mathrm{DYS} \rightarrow$ SCC (case 29), reversely correlated to the aggravation states of the ESCC disease.

\subsection{RT-PCR}

To further verify the unusual expression of SCCA1 in transcription level, RT-PCR experiment was performed to compare the mRNA levels in tumor and non-tumor tissues. Figure 8 shows the RT-PCR results for three representative pairs of the tissue samples. With the mRNA of beta-actin as internal control, the mRNA levels in non-tumor tissues are obviously higher than those in tumor tissues, suggesting that the different expression of SCCA1 takes place at transcription stage. 


\section{Discussion}

Although numerous studies in genomic field have revealed a magnitude of changes occurring in the multistage pathogenesis of ESCC, including mutations of a variety of tumor suppressor genes and oncogenes, changes in transcription, proliferation-associated factors and metastasis-related factors, these changes may not necessarily warrant subsequent corresponding alternations at the protein levels or functions [21-30]. Proteomics, which aims at characterizing the entire protein complement expressed in cells or tissues, provides complementary information and direct evidences to unravel tumor-specific molecular events during multistage carcinogenesis. In the present study, we used 2DE based proteomics to examine the protein profiles of cancer tissues and the adjacent non-tumor tissues freshly collected from Linzhou, the highest ESCC incident area in northern China, to identify proteins related to esophageal malignancy. A total of 20 proteins were uncovered with differential expressions in esophageal carcinogenesis, among which 15 were up-regulated and 5 were down-regulated.

The first intriguing identification is SCC antigen, SCCA1, which was found underexpressed in ESCC. Initially isolated from human cervical SCC tissue [31], SCCA belongs to a serine protease inhibitor family (serpins). Serpins were found to be involved in a variety of biological functions, including fibrinolysis, coagulation, inflammation, tumor cell invasion, cellular differentiation and apoptosis [32]. Biological studies have revealed that SCCA1 may function in cancer cells for tumor growth, and in normal squamous epithelium for differentiation by inhibiting apoptosis [33]. The SCC antigen was found highly upregulated in various SCC cancers including those in the uterine cervix, lung, head and neck, skin [33, $34]$ and recently in buccal mucosa [16]; this protein was therefore regarded as a SCC tumor marker. However, we observed that SCCA1 expression in ESCC cancer tissues was 
suppressed by 2.5 folds compared to adjacent normal tissues (Table 1). This unusual observation was further validated by Western blotting data, showing that the underexpression of SCCA1 not only takes place in tumor tissues in general (Fig. 7A) but also proceeds correlatively with malignant potential (Fig. 7B). A similar trend of SCCA1 downregulation in ESCC tumor was found in RT-PCR experiment (Fig. 8), suggesting its firm occurrence in transcription level. This finding, although contradictory to the results from previous studies with other SCC cancers, implicates that the SCCA1 may have a unique function in esophagus SCC tumorigenesis. In addition, the decreased expression of SCCA1 can be linearly correlated to the differentiation progression of the disease in Group 1 (Fig. 4). This finding is consistent well with early observations that patients with well-differentiated esophageal tumors tended to have higher SCCA1 levels compared to those with poorly differentiated tumors $[35,36]$. Therefore, it is likely that SCCA1 is an indicator for the histological differentiation of the ESCC [37].

A group of cytoskeleton microfilaments-associated proteins, including cytoplasmic actin, gamma-actin, transgelin, TPM1, TPM4, tubulin alpha-1 chain and tubulin beta-5 chain, were found to express differentially between cancer and normal tissues. Actin network is essential for cellular functions such as motility, division and cell surface receptor movement, anchorage dependence, and contact inhibition. During malignant transformation, expression alternations in actin microfilament network and other actin-associated proteins always accompany morphological changes [38-41]. Previous studies have demonstrated that expression changes in cytoskeleton-associated proteins, including actin, TPM, gelsolin, caldesmon, myosin light chain, have been implicated in transformed phenotypes [41].

Tropomyosin (TPM) is a major structural component of cytoskeletal microfilament and multiple TPM isoforms have been reported in cultured non-muscle cells. Interestingly, 
opposite expression regulations for different TPM isoforms have been often found in tumors, implying that these isoforms may have different functions in cell transformation. For example, under-expressions of high MW TPM have been reported in various cancers such as oral tongue squamous cell carcinoma [15], breast [39, 42] and colon [42] cancers. Up-regulation of lower MW TPM isoforms has been implicated to be associated with metastatic potential of primary breast carcinoma [43], melanoma [44] and Lewis lung carcinoma [45]. Our current data validated the different regulations of TPM isoforms, with TPM1 being down-regulated and TPM4 being up-regulated significantly in ESCC tissues. The reverse regulation changes of TPM isoforms may cause an imbalance in normal phenotypes of epithelial microfilament and lead to malignant morphological changes of aberrant cells. These alterations may provide clues related to early detection and diagnosis and to the identification of therapeutic targets.

Transgelin is another cytoskeleton-associated protein related to cell transformation, division, adherence and migration. Contradictory results concerning transgelin expression in tumors have been reported. For example, a proteomic analysis of matched normal ductal/lobular units and ductal carcinoma in situ (DCIS) of the human breast revealed that transgelin expression was at higher level in normal ductal epithelial cells than in DCIS cells [13]. Transgelin gene expression at mRNA level was greatly reduced or lost in transformed and tumor cell lines [42]. However, a recent protein profile study discovered that transgelin was over-expressed in stomach cancer tissue [46]. Our current observation testified that transgelin expression was dramatically increased in ESCC, with a phenomenon that one distinct transgelin isoform (spot 808) presents exclusively in the cancer tissues (Fig. 3). Given the fact that esophagus and stomach are closely related in digestive tract, ESCC and stomach cancer may be subjected to a similar stimulation in term of cell malignant 
transformation related to transgelin expression. The underlying nature of transgelin functions in the tumorigenesis of esophagus and stomach warrants further investigation.

Accumulating evidence has indicated that intracellular redox state plays important roles in cellular signal transduction and gene expression [47]. Reactive oxygen species (ROS), which are produced in cells during physiological processes in response to external stimuli, can affect intracellular redox state. At low levels, ROS modulate gene expression through modulating cellular redox state; at high levels, ROS are highly deleterious and potentially damage DNA, proteins, carbohydrates and lipids. It has been suggested that ROS play roles in all stages of carcinogenesis, including initiation, promotion, and progression [48]. In order to protect themselves from oxidative radical stress, cells have developed defense systems that comprise proteins superoxide dismutases (SOD), catatalse, glutathione peroxidases, and preoxiredoxins (PRX). The up-regulations of MnSOD and PRX1 in ESCC and their linear correlations with progression of disease from pre-malignant to invasive cancer (Fig. 5) reflect the cell defense effort in maintaining intracellular homeostasis. Similar observations have been found in other cancers including the over-expression of PRX in malignant mesothelioma [49], lung cancer [50] and oral cancer [51], and over-expression of MnSOD in human prostate cancer cell lines [52] and in buccal SCC [16]. Interestingly, a minor down-regulation of PRX2 isoform was detected in ESCC, suggesting that different PRX isoforms may have slightly different functions unique to the esophageal neoplasms.

Alpha B crystalline is a member of small heat shock proteins (HSPs) which are ubiquitous chaperon molecules related to stresses. They can protect cells from damage through binding to partially denatured proteins, dissociating protein aggregates, modulating the correct folding, and cooperating in transporting newly synthesized polypeptides to the target organelles [53]. $\alpha \mathrm{B}$-Cryst was able to inhibit both the mitochondrial and death receptor 
apoptotic pathways through abolishing the autoproteolytic maturation of partially processed caspase-3 intermediate [54]. Intriguingly, while other HSPs were usually up-regulated in tumors, $\alpha \mathrm{B}$-Cryst was often down-regulated in various cancers [15, 55-59]. Our present data reinforced this observation with $\alpha \mathrm{B}$-Cryst being markedly suppressed in ESCC tissues. These results again revealed that $\alpha B$-Cryst plays a role distinctive from other HSPs in carcinogenesis and implicated that under-expression of $\alpha \mathrm{B}$-Cryst may be a general marker for various tumors.

Stratifin, also known as $14-3-3 \sigma$ or HME-1, was recently reported to be a candidate tumor suppressor gene that is transactivated by p53 in response to DNA damage and negatively regulates both $\mathrm{G} 1 / \mathrm{S}$ and $\mathrm{G} 2 / \mathrm{M}$ cell cycle progression $[60,61]$. Over-expression of stratifin increased stabilization of p53 through blocking Mdm2-mediated p53 ubiquitination and enhanced oligomerization of p53, leading to an increase in p53 transcriptional activity [62]. Several studies have reported the potent role of stratifin in tumorigenesis of various organs, including prostate, urinary bladder, and breast $[18,63,64]$. In line with other published data, a small but significant under-expression of stratifin was found in cancer tissues in the present study, implicating its probable contribution to pathogenesis of esophageal neoplasms. Additionally, the stratifin expression was inversely correlated with differentiation grade of ESCC (Fig. 4), indicating that malignant cells arising from esophageal epithelium may lose stratifin in progressive dedifferentiation.

Another potential tumor suppressor protein, prohibitin was revealed to be differentially expressed between cancer tissue and adjacent normal epithelium. Interestingly, prohibitin expression positively correlated with the progression of precancerous lesions (Fig. 5) but inversely correlated with the differentiation grades of squamous cell carcinoma of esophagus (Fig 4). This expression manner indicates that prohibitin may play different roles at different 
stages of esophageal tumorigenesis by acting on cell proliferation. One study using RNA interference to knock down prohibitin and using transient transfection to over-express the protein demonstrated that cells with reduced prohibitin displayed a slight increase in the percentage of cell population in cell cycle, while cells with increased prohibitin showed a clear reduction in the percentage entering cell cycle following dihydrotestosterone stimulation [65].

In summary, we used 2D-gel based proteomics to compare the protein profiles between ESCC tumor and matched surrounding tissues and to identify differently expressed proteins in the esophageal cancer. A number of tumor-associated proteins including SCCA1, transgelin, TPM, prohibitin, PRX, $\alpha \mathrm{B}$-Cryst and MnSOD was detected with altered expressions, corresponding to a complicated multi-step process involved in the initiation, formation and progression of esophageal carcinoma. When the expressions of the proteins were correlated with the histological stages and differentiation status of ESCC tissues, linear progressions were found for most of the altered proteins, providing a rational to understand the relationships between the functions of the tumor-associated proteins and the cell malignant transformation in esophageal tumorigenesis. 


\section{Acknowledgements}

We wish to thank Yuan Zhou, Ruiqing Jiao, Cynthie Y. H. Cheung and Guocui Yang for their skillful technical assistance for the completion of this study. We are also grateful for Prof. Songliang Qiu for the review of histological classification of H\&E tissue slides. We also thank Jilin Li for collecting samples, Zongmin Fan and Yanjie Li for helping prepare the tissue processing and photographs of H\&E slides. This work was partially supported by Hong Kong Research Grants Council Grants HKU 7227/02M (to Q.Y.H.) and HKU 7218/02M (to J.F.C.), the Department of Chemistry, the Areas of Excellence scheme of Hong Kong University Grants Committee, and the National Outstanding Young Scientist Award 30025016 (China). 


\section{References}

[1] Yang, C. S., Cancer Res. 1980, 40, 2633-2644.

[2] Li, J. Y., Liu, B. Q., Li, G. Y., Chen, Z. J. et al, Int. J. Epidemiol. 1981, 10, 127-133.

[3] Clark, G. W., Roy, M. K., Corcoran, B. A., Carey, P. D., Surg. Oncol. 1996, 5, 149-164.

[4] Oka, M., Yamamoto, K., Takahashi, M., Hakozaki, M. et al, Cancer Res. 1996, 56, 2776-2780.

[5] Hu, J., Nyren, O., Wolk, A., Bergstrom, R. et al, Int. J. Cancer 1994, 57, 38-46.

[6] Cheng, K. K., Duffy, S. W., Day, N. E., Lam, T. H., Int. J. Cancer 1995, 60, 820-822.

[7] Garidou, A., Tzonou, A., Lipworth, L., Signorello, L. B. et al, Int. J. Cancer 1996, 68, 295-299.

[8] Hunt, D. F., J. Proteome. Res. 2002, 1, 15-19.

[9] He, Q. Y. \& Chiu, J. F., J. Cell Biochem. 2003, 89, 868-886.

[10] Kim, J., Kim, S. H., Lee, S. U., Ha, G. H. et al, Electrophoresis 2002, 23, 4142-4156.

[11] Chen, G., Gharib, T. G., Huang, C. C., Thomas, D. G. et al, Clin. Cancer Res. 2002, 8, 2298-2305.

[12] Meehan, K. L., Holland, J. W., Dawkins, H. J., Prostate 2002, 50, 54-63.

[13] Wulfkuhle, J. D., Sgroi, D. C., Krutzsch, H., McLean, K. et al, Cancer Res. 2002, 62, 6740-6749.

[14] Klade, C. S., Voss, T., Krystek, E., Ahorn, H. et al, Proteomics. 2001, 1, 890-898.

[15] He, Q. Y., Chen, J., Kung, H. F., Yuen, A. P. et al, Proteomics. 2004, 4, 271-278.

[16] Chen, J., He, Q. Y., Yuen, A. P., Chiu, J. F., Proteomics 2004, 4, 2465-2475.

[17] Zhang, L. Y., Ying, W. T., Mao, Y. S., He, H. Z. et al, World J. Gastroenterol. 2003, 9, 650-654.

[18] Moreira, J. M., Gromov, P., Celis, J. E., Mol. Cell Proteomics. 2004, 3, 410-419.

[19] Srisomsap, C., Sawangareetrakul, P., Subhasitanont, P., Panichakul, T. et al, Proteomics. 2004, 4, 1135-1144.

[20] He, Q. Y., Lau, G. K., Zhou, Y., Yuen, S. T. et al, Proteomics. 2003, 3, 666-674.

[21] Xing, E. P., Nie, Y., Wang, L. D., Yang, G. Y. et al, Carcinogenesis 1999, 20, 77-84.

[22] Cai, Y. C., Yang, G. Y., Nie, Y., Wang, L. D. et al, Carcinogenesis 2000, 21, 683-689.

[23] Xing, E. P., Nie, Y., Song, Y., Yang, G. Y. et al, Clin. Cancer Res. 1999, 5, 2704-2713. 
[24] Shi, S. T., Yang, G. Y., Wang, L. D., Xue, Z. et al, Carcinogenesis 1999, 20, 591-597.

[25] Montesano, R., Hollstein, M., Hainaut, P., Int. J. Cancer 1996, 69, 225-235.

[26] Yang, G., Zhang, Z., Liao, J., Seril, D. et al, Int. J. Cancer 1997, 72, 746-751.

[27] Shimoyama, S., Konishi, T., Kawahara, M., Aoki, F. et al, Hepatogastroenterology 1998, 45, 1497-1504.

[28] Shibagaki, I., Shimada, Y., Wagata, T., Ikenaga, M. et al, Cancer Res. 1994, 54, 29963000 .

[29] Yu, C. C. \& Filipe, M. I., Histochem. J. 1993, 25, 843-853.

[30] Gerdes, J., Schwab, U., Lemke, H., Stein, H., Int. J. Cancer 1983, 31, 13-20.

[31] Kato, H., Morioka, H., Aramaki, S., Torigoe, T., Cell Mol. Biol. Incl. Cyto. Enzymol. $1979,25,51-56$.

[32] Silverman, G. A., Bird, P. I., Carrell, R. W., Church, F. C. et al, J. Biol. Chem. 2001, 276, 33293-33296.

[33] Suminami, Y., Nawata, S., Kato, H., Tumour. Biol. 1998, 19, 488-493.

[34] Torre, G. C., Tumour. Biol. 1998, 19, 517-526.

[35] Gion,M., Mione,R., Dittadi,R., Bruscagnin,G., Tremolada,C., Zari,C., \& Dalla Palma,P. (1987) SCC antigen in patients with esophageal carcinoma. In SCC Antigen in the Management of Squamous Cell Carcinoma (Kato,H., de Bruijn,H.W.A., Ebert,W., Herberman,R.B., \& Johnson,J.T., eds), pp. 130-141. Excerpta Medica, Princeton.

[36] Hirata, S., Yamazaki, K., Yokoyama, Y., Ueda, M. et al, Nippon Geka Gakkai Zasshi 1989, 90, 267-272.

[37] Matsuda, H., Mori, M., Tsujitani, S., Ohno, S. et al, Cancer 1990, 65, 2261-2265.

[38] Shapland, C., Hsuan, J. J., Totty, N. F., Lawson, D., J. Cell Biol. 1993, 121, 1065-1073.

[39] Raval, G. N., Bharadwaj, S., Levine, E. A., Willingham, M. C. et al, Oncogene 2003, 22, 6194-6203.

[40] Bharadwaj, S. \& Prasad, G. L., Cancer Lett. 2002, 183, 205-213.

[41] Button, E., Shapland, C., Lawson, D., Cell Motil. Cytoskeleton 1995, 30, 247-251.

[42] Shields, J. M., Rogers-Graham, K., Der, C. J., J. Biol. Chem. 2002, 277, 9790-9799.

[43] Franzen, B., Linder, S., Uryu, K., Alaiya, A. A. et al, Br. J. Cancer 1996, 73, 909-913.

[44] Miyado, K., Kimura, M., Taniguchi, S., Biochem. Biophys. Res. Commun. 1996, 225, 427-435.

[45] Takenaga, K., Nakamura, Y., Sakiyama, S., Mol. Cell Biol. 1988, 8, 3934-3937. 
[46] Ryu, J. W., Kim, H. J., Lee, Y. S., Myong, N. H. et al, J. Korean Med. Sci. 2003, 18, 505-509.

[47] Kamata, H. \& Hirata, H., Cell Signal. 1999, 11, 1-14.

[48] Klaunig, J. E., Xu, Y., Isenberg, J. S., Bachowski, S. et al, Environ. Health Perspect. 1998, 106 Suppl 1, 289-295.

[49] Kinnula, V. L., Lehtonen, S., Sormunen, R., Kaarteenaho-Wiik, R. et al, J. Pathol. 2002, 196, 316-323.

[50] Chang, J. W., Jeon, H. B., Lee, J. H., Yoo, J. S. et al, Biochem. Biophys. Res. Commun. 2001, 289, 507-512.

[51] Yanagawa, T., Iwasa, S., Ishii, T., Tabuchi, K. et al, Cancer Lett. 2000, 156, 27-35.

[52] Zhong, W., Yan, T., Webber, M. M., Oberley, T. D., Antioxid. Redox. Signal. 2004, 6, 513-522.

[53] Hartl, F. U., Nature 1996, 381, 571-579.

[54] Kamradt, M. C., Chen, F., Sam, S., Cryns, V. L., J. Biol. Chem. 2002, 277, 3873138736.

[55] Kato, K., Ito, H., Hasegawa, K., Inaguma, Y. et al, J. Neurochem. 1996, 66, 946-950.

[56] Kato, M., Herz, F., Brijlall, D., Kato, S., Experientia 1994, 50, 479-482.

[57] Klemenz, R., Scheier, B., Muller, A., Steiger, R. et al, Verh. Dtsch. Ges. Pathol. 1994, $78,34-35$.

[58] Hitotsumatsu, T., Iwaki, T., Fukui, M., Tateishi, J., Cancer 1996, 77, 352-361.

[59] Takashi, M., Sakata, T., Ohmura, M., Kato, K., Urol. Res. 1997, 25, 173-177.

[60] Hermeking, H., Lengauer, C., Polyak, K., He, T. C. et al, Mol. Cell 1997, 1, 3-11.

[61] Laronga, C., Yang, H. Y., Neal, C., Lee, M. H., J. Biol. Chem. 2000, 275, 23106-23112.

[62] Yang, H. Y., Wen, Y. Y., Chen, C. H., Lozano, G. et al, Mol. Cell Biol. 2003, 23, 70967107.

[63] Cheng, L., Pan, C. X., Zhang, J. T., Zhang, S. et al, Clin. Cancer Res. 2004, 10, 30643068 .

[64] Simpson, P. T., Gale, T., Reis-Filho, J. S., Jones, C. et al, J. Pathol. 2004, 202, 274-285.

[65] Gamble, S. C., Odontiadis, M., Waxman, J., Westbrook, J. A. et al, Oncogene 2004, 23, 2996-3004. 
Table 1 Histopathological classification of ESCC specimens used for 2D-gel proteomic analysis.

\begin{tabular}{|c|c|c|c|c|c|c|c|c|}
\hline & & \multicolumn{4}{|c|}{ Control \& Pre-tumor } & \multicolumn{3}{c|}{ SCC } \\
\hline & & Normal & BCH & DYS & CIS & Well & Moderate & Poor \\
\hline Group 1 & & 15 & - & - & - & 1 & 5 & 9 \\
\hline Group 2 & Case 23 & - & - & 1 & 1 & - & 1 & - \\
& Case 29 & - & 1 & 1 & - & - & 1 & - \\
\hline
\end{tabular}

Normal, normal esophageal epithelium; BCH, basal cell hyperplasia; DYS, dysplasia; CIS, carcinoma in situ; SCC, squamous cell carcinoma; Well, well-differentiated SCC; Moderate, moderately-differentiated SCC; Poor, poorly-differentiated SCC. 
Table 2. Summary of peptide mass fingerprinting and statistical differences and $p$ values for the comparison between normal and cancer tissues.

\begin{tabular}{|c|c|c|c|c|c|c|c|c|}
\hline Spot No. & Protein ID (MW/pI) & $\begin{array}{l}\text { Experimental } \\
\mathrm{MW}(\mathrm{kDa}) / \mathrm{pI}\end{array}$ & $\begin{array}{l}\text { Peptides } \\
\text { matched }\end{array}$ & $\begin{array}{c}\text { Sequence } \\
\text { coverage }(\%)\end{array}$ & $\begin{array}{r}\text { Total mass } \\
\text { error }(\mathrm{ppm})\end{array}$ & $\begin{array}{l}\text { MOWSE } \\
\text { score }\end{array}$ & $\begin{array}{l}\text { Differential } \\
\text { ratio }\end{array}$ & $\mathrm{p}$ value \\
\hline 304 & Alpha enolase $(47 \mathrm{kDa} / 6.99)$ & $49 / 7.0$ & 43 & 74 & 15.6 & $3.73 \mathrm{e}+12$ & +1.8 & $9.191 \mathrm{E}-05$ \\
\hline 309 & Alpha enolase $(47 \mathrm{kDa} / 6.99)$ & $49 / 6.5$ & 27 & 57 & 20 & $3.87 \mathrm{e}+07$ & +1.7 & 0.0018 \\
\hline 310 & Alpha enolase $(47 \mathrm{kDa} / 7.0)$ & $49 / 6.8$ & 44 & 67 & 17.4 & $1.74 \mathrm{e}+13$ & +1.7 & 0.0001 \\
\hline 344 & Elongation factor $\mathrm{Tu}(\mathrm{P} 43)(45 \mathrm{kDa} / 6.31)$ & $48 / 6.5$ & 10 & 16 & 18.8 & 301 & +2.0 & 0.0081 \\
\hline 349 & $\begin{array}{l}\text { Isocitrate dehydrogenase [NADP] cytoplasmic (46.7 } \\
\mathrm{kDa} / 6.53)\end{array}$ & $48 / 6.5$ & 29 & 61 & 21.4 & $1.01 \mathrm{e}+08$ & +2.1 & 0.0005 \\
\hline 376 & SCCA1 $(45 \mathrm{kDa} / 6.3)$ & $46 / 6.5$ & 25 & 71 & 16.1 & $2.46 \mathrm{e}+07$ & -2.5 & $6.474 \mathrm{E}-06$ \\
\hline 386 & Tropomyosin $1(34 \mathrm{kDa} / 4.9)$ & $37 / 4.6$ & 13 & 45 & 11 & 729 & -1.7 & 0.0066 \\
\hline 456 & Tubulin alpha-1 chain and actin cytoplasmic $150 \mathrm{kDa} / 4.94)$ & $40 / 4.8$ & 9 & 21 & 10.3 & $5.90 \mathrm{e}+05$ & +4.0 & 4.394E-06 \\
\hline 484 & Tubulin beta-5 chain $(50 \mathrm{kDa} / 4.78)$ & $50 / 4.8$ & 9 & 26 & 25.4 & 1450 & +5.2 & 0.0105 \\
\hline 512 & Glyceraldehyde 3-phosphate dehydrogenase (36 kDa/8.58) & $35 / 8.0$ & 6 & 19 & 16.1 & 234 & +1.8 & 0.0028 \\
\hline 534 & Tropomyosin $4(27.5 \mathrm{kDa} / 4.8)$ & $37 / 4.5$ & 35 & 66 & 18.3 & $3.07 \mathrm{e}+04$ & +2.7 & 0.0109 \\
\hline 536 & Gamma-actin $(41.7 \mathrm{kDa} / 5.3)$ & $39 / 5.0$ & 10 & 24 & 13.2 & $1.08 \mathrm{e}+04$ & +2.5 & 0.0001 \\
\hline 538 & Glyceraldehyde 3-phosphate dehydrogenase (36 kDa/8.6) & $35 / 8.5$ & 16 & 47 & 14.2 & $2.60 \mathrm{e}+04$ & +5.3 & $8.882 \mathrm{E}-06$ \\
\hline 546 & Glyceraldehyde 3-phosphate dehydrogenase (36 kDa/8.6) & $35 / 8.5$ & 10 & 25 & 24.5 & 1005 & +2.1 & 0.0133 \\
\hline 550 & Tropomyosin isoform $(29 \mathrm{kDa} / 4.8)$ & $37 / 4.5$ & 13 & 56 & 18.5 & 1383 & +2.0 & 0.0029 \\
\hline 586 & Stratifin $(28 \mathrm{kDa} / 4.7)$ & $28 / 4.5$ & 8 & 36 & 14.1 & 167 & -1.5 & 0.0211 \\
\hline 592 & Prohibitin $(30 \mathrm{kDa} / 5.6)$ & $29 / 5.5$ & 10 & 29 & 12.9 & 2131 & +1.5 & 0.0075 \\
\hline 701 & Peroxiedoxin 1 (22 kDa/8.3) & $24 / 8.0$ & 17 & 51 & 16.4 & $7.73 \mathrm{e}+06$ & +2.5 & 0.0003 \\
\hline 706 & Manganese-containing superoxied dismutase $(23.7 \mathrm{kDa} / 6.9)$ & $24 / 7.0$ & 12 & 57 & 19.9 & $1.60 \mathrm{e}+05$ & +1.7 & 0.0015 \\
\hline 714 & Peroxiredoxin $2(22 \mathrm{kDa} / 5.7)$ & $23 / 5.5$ & 6 & 25 & 9.4 & 281 & -1.5 & 0.0350 \\
\hline 743 & Alpha B crystalline $(21 \mathrm{kDa} / 6.7)$ & $21 / 7.0$ & 8 & 34 & 33.3 & 2530 & -5.9 & 0.0020 \\
\hline 795 & Neuronal protein $(31.5 \mathrm{kDa} / 8.1)$ & $20 / 8.1$ & 6 & 23 & 23.3 & 597 & +4.2 & $9.276 \mathrm{E}-05$ \\
\hline 806 & Transgelin (SM22-alpha) $(22.6 \mathrm{kDa} / 8.9)$ & $20 / 8.5$ & 18 & 49 & 12.7 & $6.13 \mathrm{e}+04$ & +2.42 & 0.0024 \\
\hline 808 & Transgelin (SM22-alpha) $(22.6 \mathrm{kDa} / 8.9)$ & $20 / 8.6$ & 16 & 63 & 18.8 & $1.55 \mathrm{e}+04$ & +107 & 0.0009 \\
\hline
\end{tabular}




\section{Figure Legends}

Figure 1. Representative histology of normal esophageal epithelium, basal cell hyperplasia (BCH), dysplasia (DYS), carcinoma in situ (CIS), and esophageal squamous cell carcinoma (SCC). Normal esophageal epithelium displays basal membrane, basal cells 1 to 3 layers (arrow head), suprabasal cells 5 to 7 layers and superficial layers; BCH shows more than 3 layers of proliferation of basal cells (arrow head); DYS features loss of architectural orientation and comprises deranged cells with various size and shape and large deeply stained nuclei; CIS comprises malignant cells occupying the entire thickness of esophageal epithelium with intact basal membrane (dotted arrow); SCC comprises numerous malignant cells characterized by considerable pleomorphism and mitotic figures (arrow head).

Figure 2. Representative images of 2D-gel for cancer (A) verses normal (B) tissue samples, respectively. The numbers indicated on map represents protein spots with differential expression.

Figure 3. Cropped images of protein spots 806 and 808 (Transgelin) in 3 pairs of ESCC samples. Transgelin isoform (808) presents exclusively on 2D-gels of cancer tissues.

Figure 4. Correlation of protein expression with differentiation status of ESCC. Well, welldifferentiated squamous cell carcinoma; Moderate, moderately-differentiated squamous cell carcinoma; Poorly, poorly-differentiated squamous cell carcinoma. Numbers in brackets are correlated protein spots on 2D maps.

Figure 5. Expression of proteins TPM4, prohibitin, PRX1, and MnSOD in the two cases with precancerous lesions. Numbers in brackets represent protein spots on 2D maps.

Figure 6. Protein confirmation for SCCA1, TPM1 and $\alpha \mathrm{B}$-Cryst by 2D Western blotting.

Figure 7. Western blots showing the protein expressions for SCCA1, TPM1 and $\alpha \mathrm{B}-\mathrm{Cryst}$ in 
tissues (T, tumor; N, normal) of Group 1 (A); and SCCA1 expression in pre-tumorous tissues of Group 2 (B).

Figure 8. RT-PCR results for three representative pairs of tissue samples, showing that the mRNA level of SCCA1 is lower in tumor than that in non-tumor tissues. $\mathrm{T}$, tumor; $\mathrm{N}$, normal. 

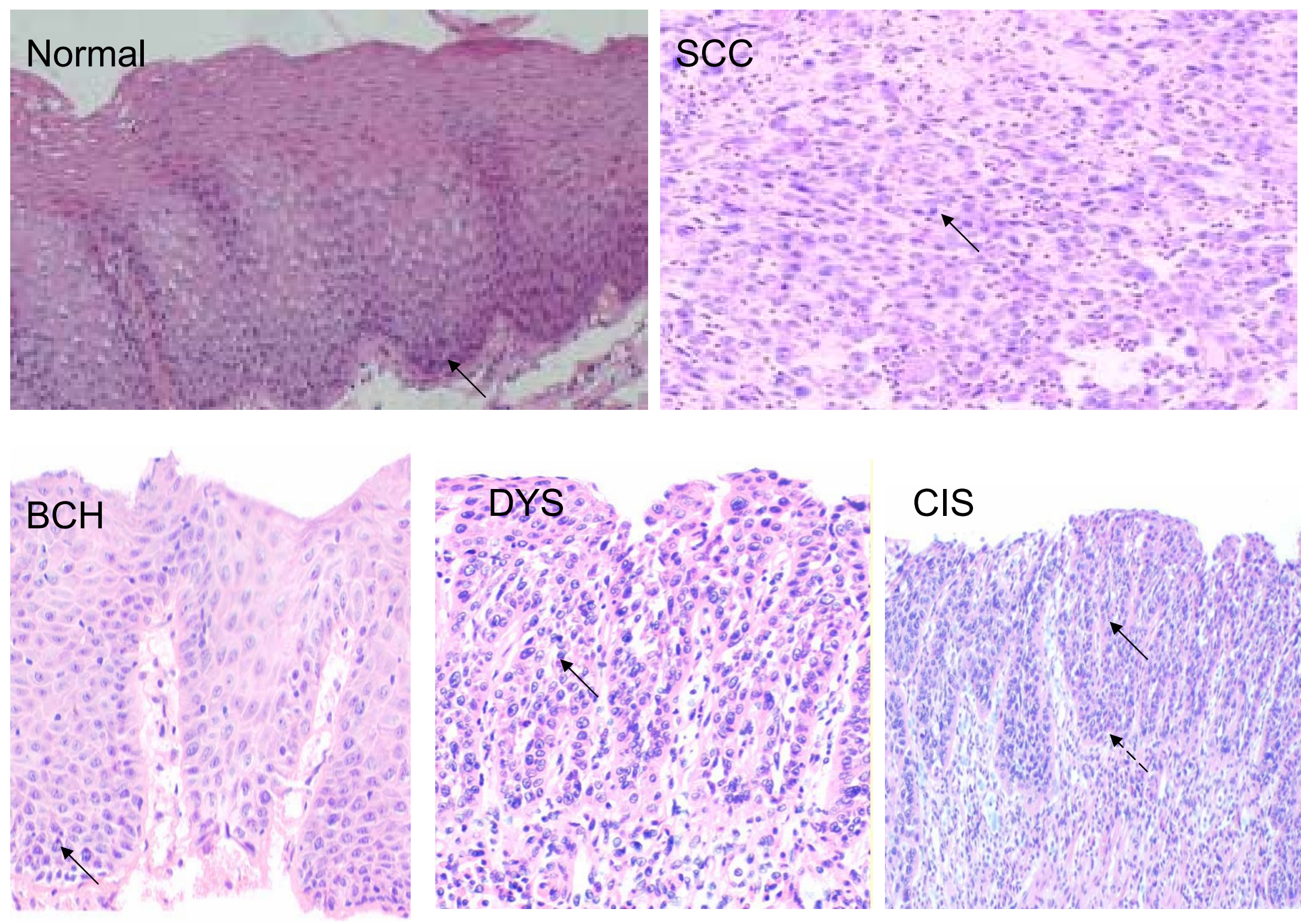

\section{DYS}

-0.0

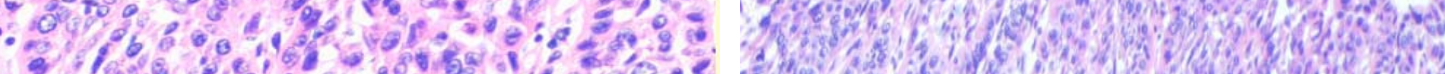
8)

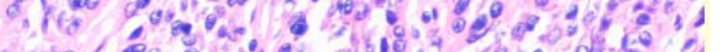

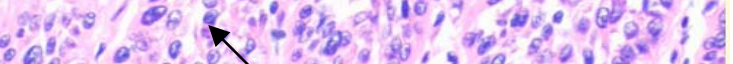

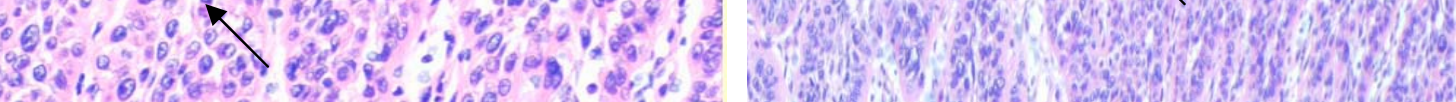
o.

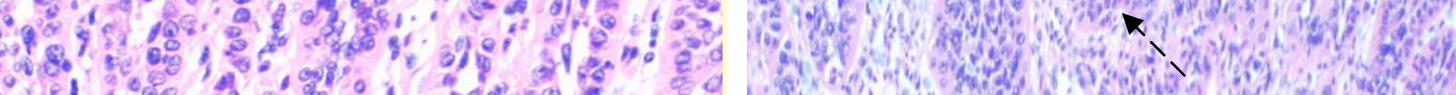

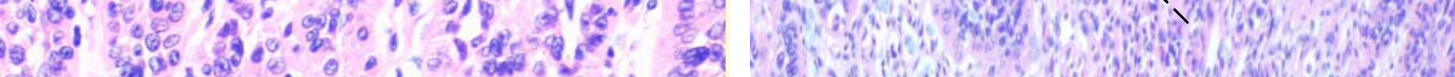

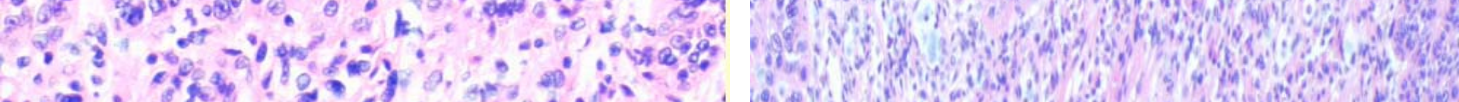

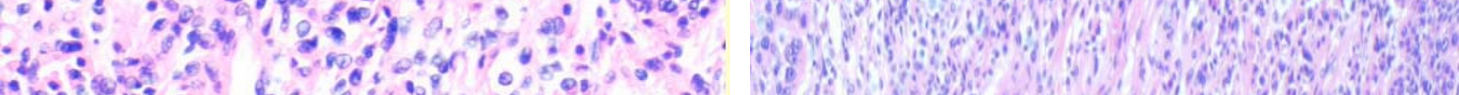
:

Figure 1 


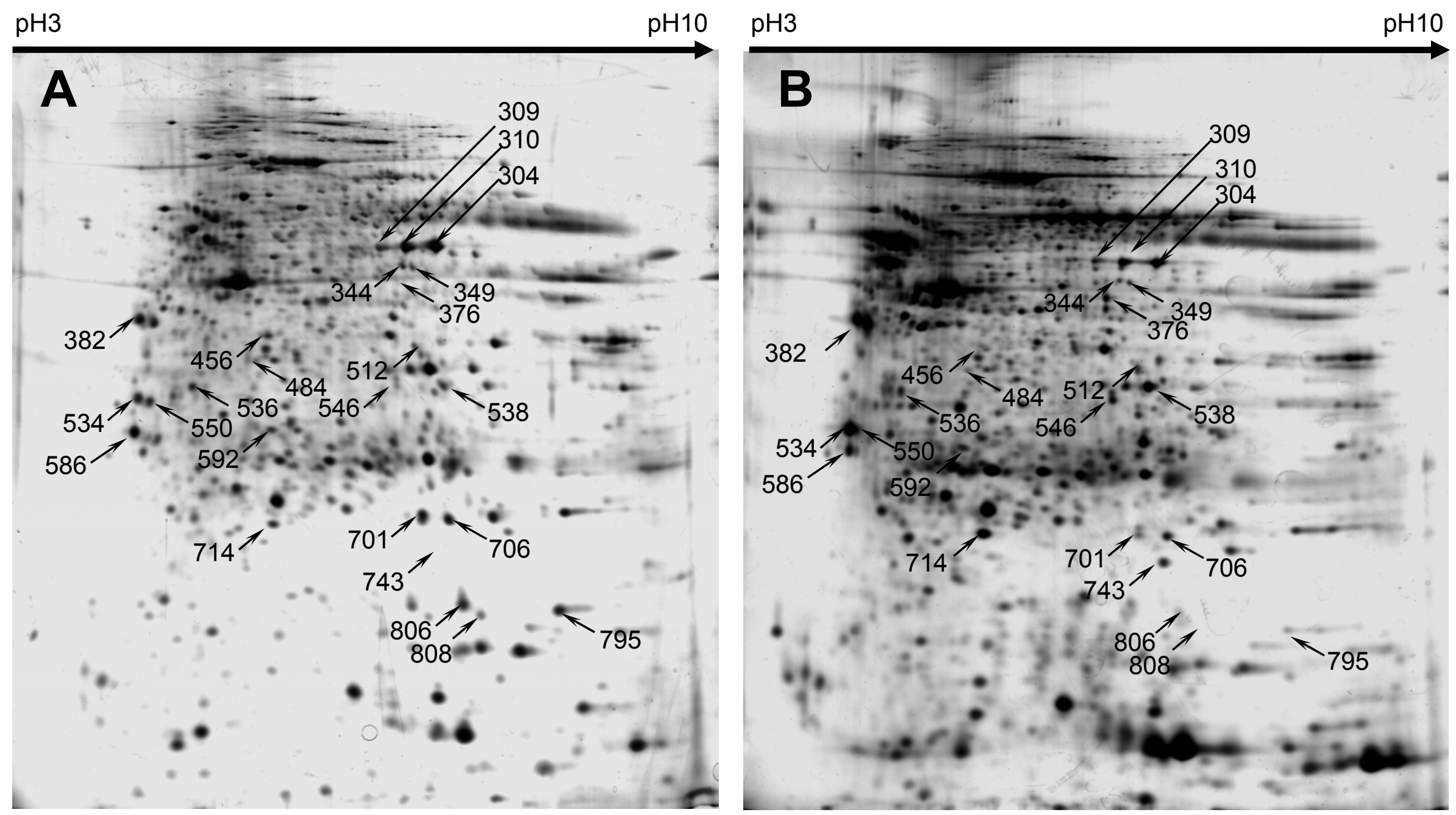

Figure 2 
Tumor
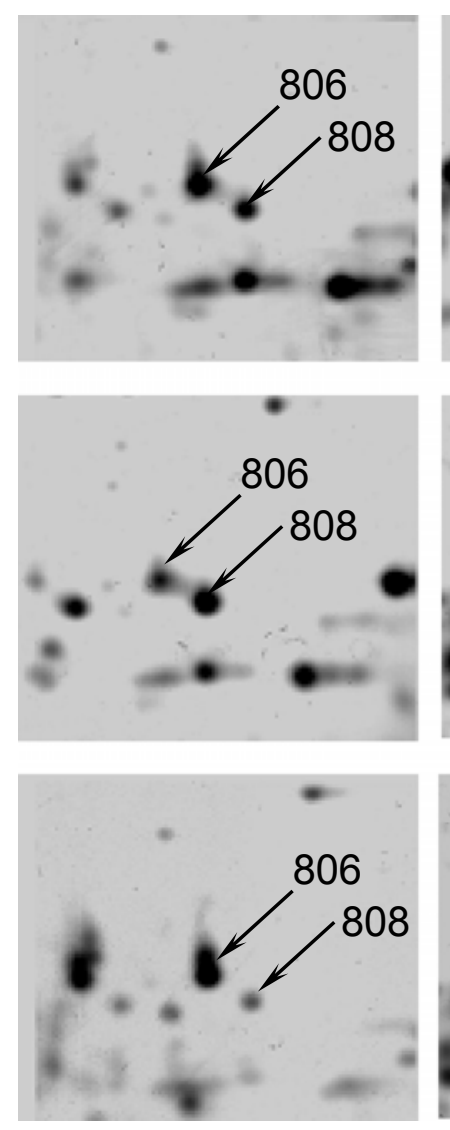

Normal
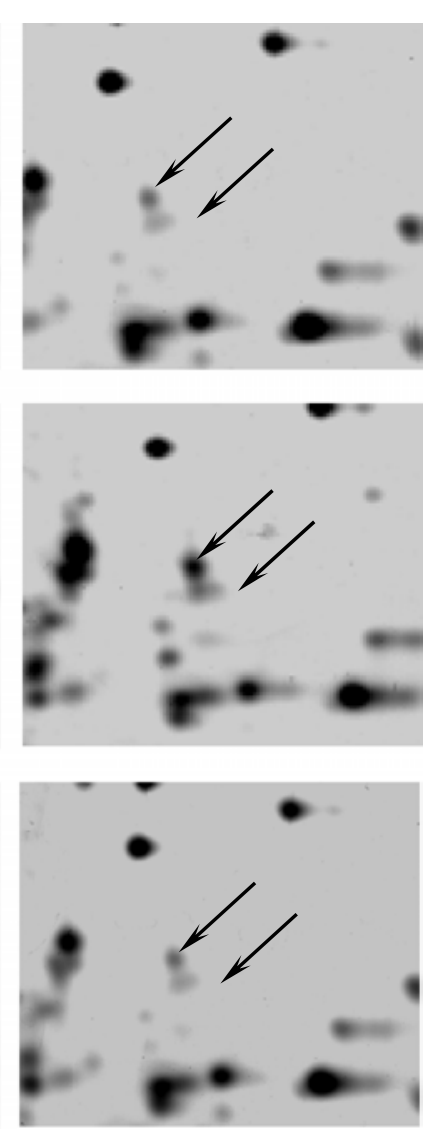

Figure 3 


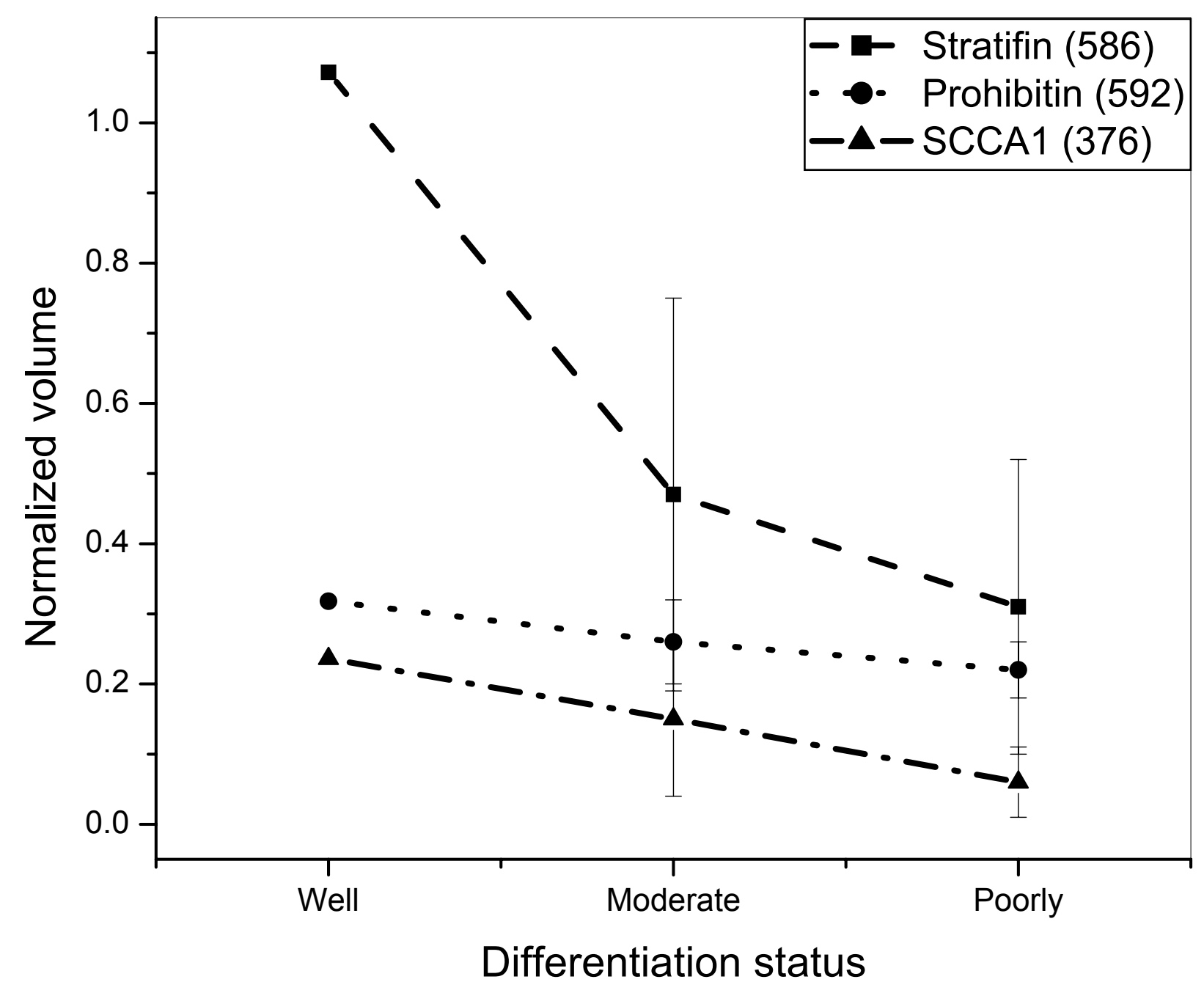

Figure 4 

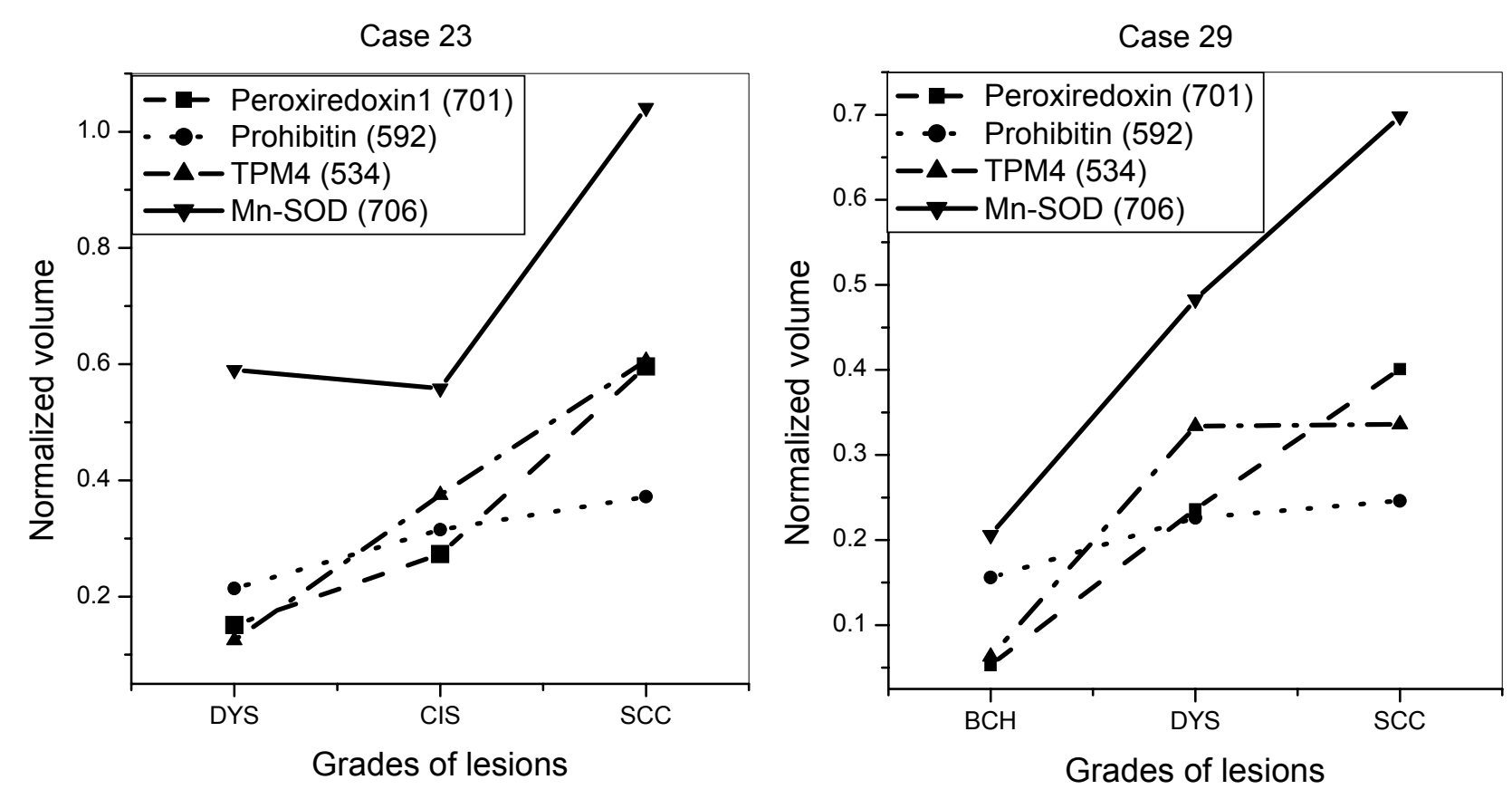

Figure 5 


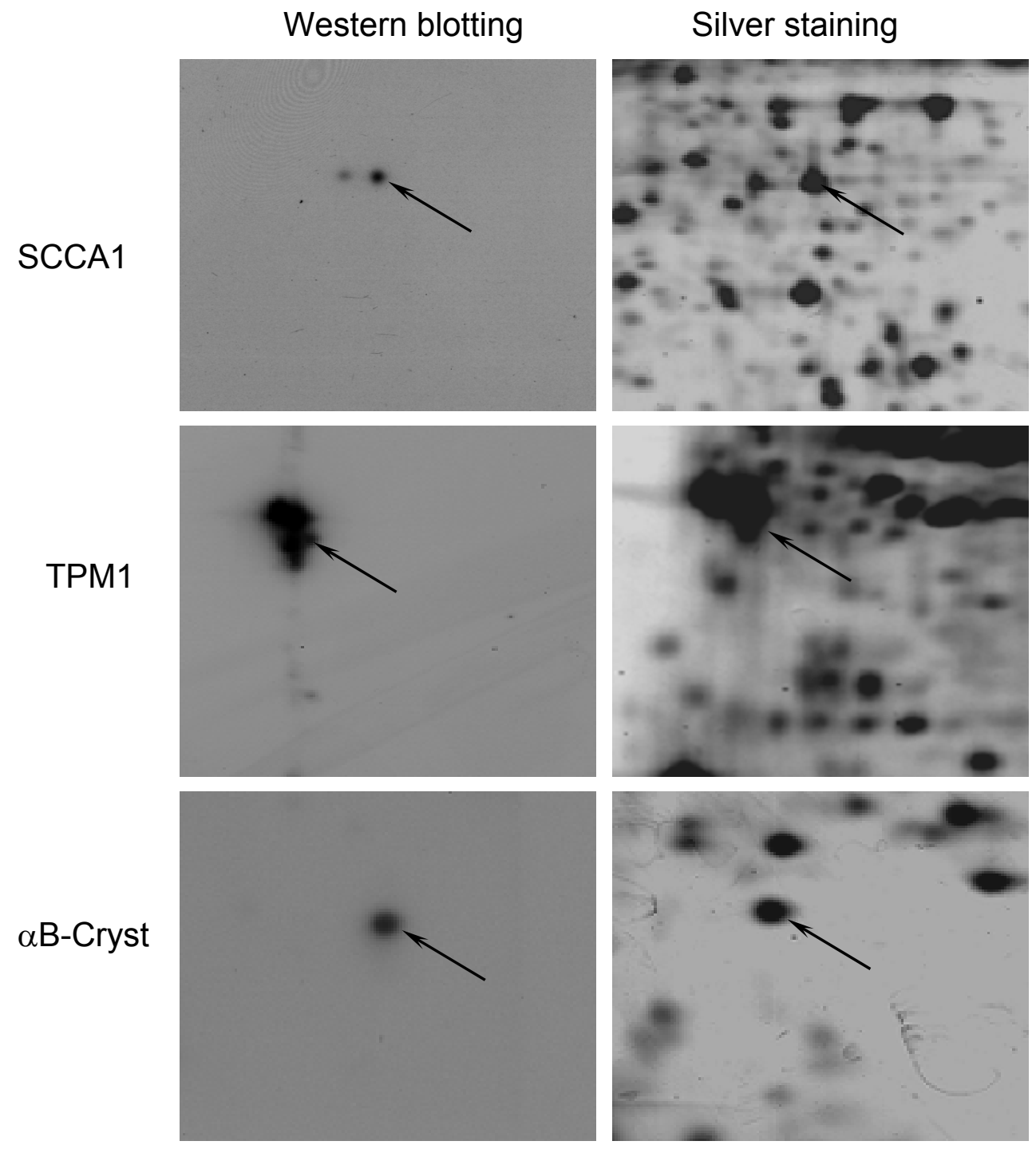

Figure 6 
A: Western blots and normalized expression levels of proteins in Group 1

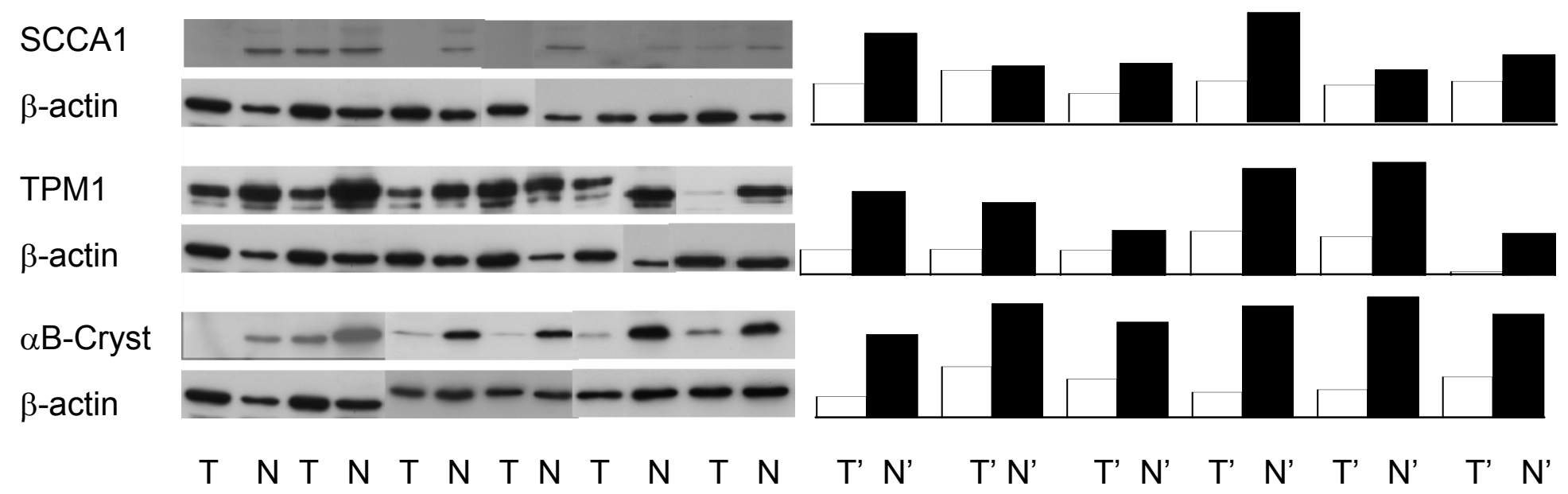

B: Western blots and normalized expression levels of SCCA1 in Group 2

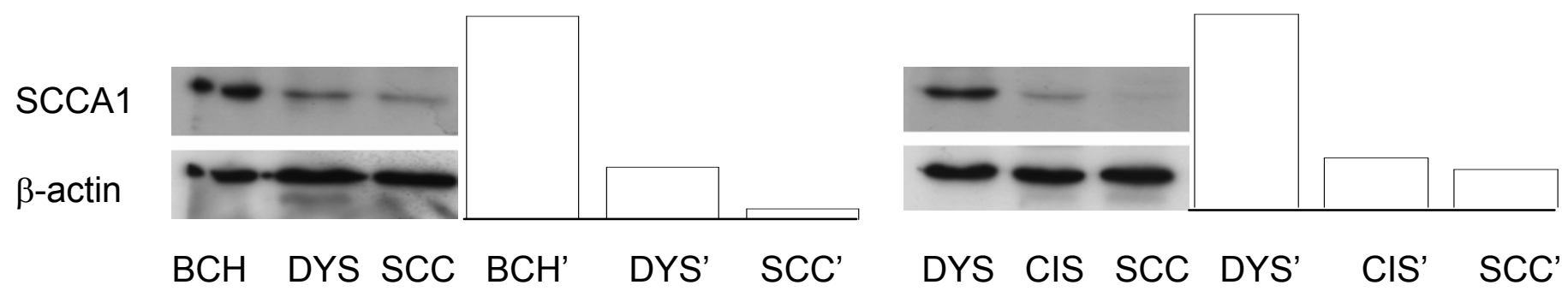




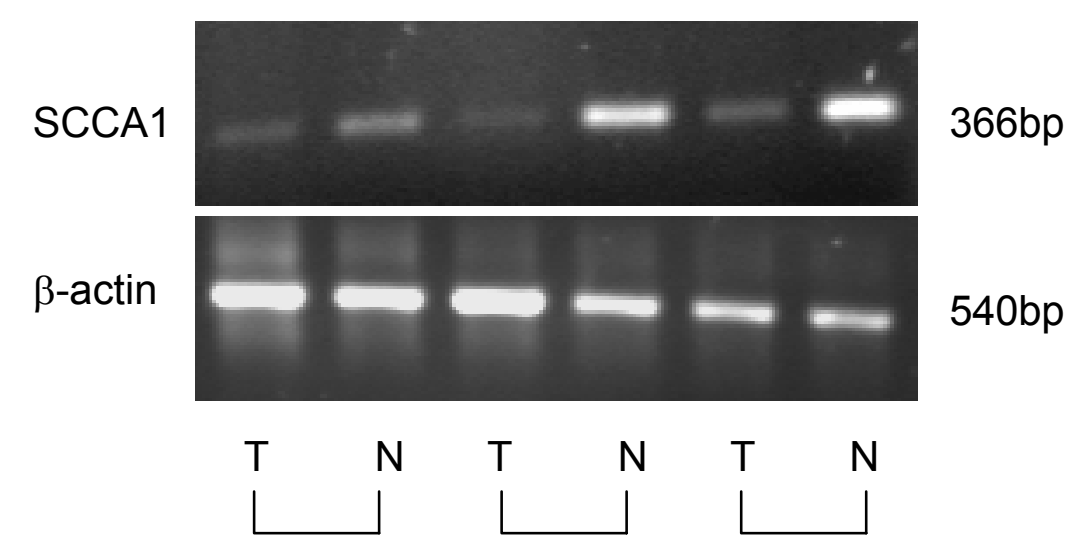

Figure 8 